\title{
Risk Perceptions of Individual vs. Institutional Investors: A Comparison Based on the Johannesburg Stock Exchange
}

\author{
Dr. Colin Firer, University of Witwatersrand, Johannesburg, South Africa \\ Dr. Michael Colin Oliver, University of Witwatersrand, Johannesburg, South Africa \\ Dr. Gail Farrelly, Rutgers University
}

\begin{abstract}
This paper examines risk at the individual, as opposed to the market, level. By means of questionnaires, individuals' risk perceptions are collected and then correlated with other measures of risk. The survey was conducted for individual investors and investment analysts in order to determine if appreciable differences exist between the two sets of respondents. The results are consistent with previous research which suggests that investors consider total risk in their share assessments. The evidence also indicates no significant differences in the risk perceptions of investors vs. those of analysts.
\end{abstract}

\section{Introduction}

Both researchers and practitioners continue to seek better risk surrogates and a more thorough understanding of how risk is perceived and priced in financial markets. One avenue of research has been to explore risk, not at the aggregate or market level, but at the level of individual perceptions of risk--see, for example, McDonald \& Stehle (1975) and Farrelly \& Reichenstein (1984). Such work, building on current perceptions of risk, is somewhat novel in that, true to the definition of risk embodied in theoretical models, an ex-ante (rather than an ex-post) approach is used. This is an appropriate response to the dilemma raised by Bowman (1982, p. 34) that: though risk is a concept relevant before the occasion (i.e., ex-ante), it essentially must be measured in actual empirical work after the occasion (i.e., ex-post).

Farrelly and Reichenstein (F\&R) ask investment professionals to rate the risk of a sample of widely held securities. The study investigates how well publicly available objective measures of risk such as beta, earnings predictability, and price stability as well as subjective measures of risk such as the dispersion of analyst forecasts and the Value Line safety rankings "explain" investor perceptions of risk. F \& $\mathrm{R}$ find that analyst risk perceptions are most highly correlated with measures of risk that are more inclusive than beta, the systematic surrogate for risk which measures the extent to which stocks move with the market. And, subjective measures of risk were found to conform more closely to analysts' risk perceptions than did objective measures.

The present research, building on this subjective component of risk, seeks to: replicate the F \& $\mathrm{R}$ study in a different market environment namely, the Johannesburg Stock Exchange; and extend the risk perception study to individuals, as well as institutional investors, so that comparisons may be drawn between the two groups.

\section{Research Methodology}

Via questionnaires--see the Appendix--respon- 
dents were asked to estimate the riskiness (on a scale of 1 to 5), over the coming year of 26 stocks. They were asked to assume that each stock was being added to a diversified stock portfolio. Questionnaires were sent to all 450 members of the Investment Analysts Society of Southern Africa; 123 responses (27.3\%) were received. They were also sent to a sample of 2500 persons on the mailing list of active investors of a firm of Johannesburg stockbrokers; 499 responses $(20 \%)$ were received.

Mean risk ratings for each share (and the standard deviation of the ratings) were calculated for each sample of investors. The ratings were then correlated with three separate measures of risk--beta, total market risk and earnings variability. (Because of the limited availability of data in South Africa, the list is more limited than that used in the American studies.) Correlation analysis, comparing individual to institutional perceptions, was also carried out, although this was limited to a certain extent by the relatively small sample size of the institutional investor group.

\section{Research Design}

\section{Data Collection}

As Carter et al. (1982, p. 52) indicate, "...the Johannesburg Stock Exchange (JSE) is composed of two broad types of stocks, namely, resource based (mainly mineral related) and industrial (manufacturing, trading and financial)." Accordingly, the present study deals with both these types of stocks, and the results for the Gold stocks are differentiated from the results for the Industrial/Financial stocks.

Two questionnaires, one for individual investors and one for institutional investors, were prepared. Each questionnaire was divided into two sections. The first section dealt with demographics and probed various facets of the investment decision making process. The results of this section of the questionnaires are not emphasized here.

This paper deals mainly with the second section of the questionnaire, the section on risk assessment. Institutional investors were asked to assess 50 stocks (25 Gold and 25 Industrial/Financial), whereas the individual investors were asked to assess only 26 (13 Gold and 13 Industrial/Financial). Since the first section of the questionnaire sent to the private investors was long and very comprehensive, it was felt that to include 50 stocks was excessive and could have increased the non-response rate significantly. The 26 stocks common to both investor groups are considered in this paper.

The Gold stocks were selected on a stratified sample basis, ensuring that the companies chosen represented all 6 Mining Houses which control or manage the Gold mines, the 5 major geographic locations in which the gold reef is mined in South Africa, mines of both short and long life, mines with low and high working costs, gold mine operations which consisted of re-working old mine dumps in order to extract residual gold, and finally, stocks with low, medium and high betas.

The Industrial/Financial stocks on the Exchange were divided into 3 groups based on their betas. Approximately equal numbers of shares were randomly selected from each group. Only shares widely traded were accepted into the sample. This was done by drawing from a population which consisted of the top $50 \%$ by trading volume of stocks on the Exchange.

One questionnaire was sent in September 1985 to all 450 members of the Investment Analysts Society of Southern Africa. They constitute the only easily accessible list of portfolio managers and investment analysts who could be regarded as the investment decision makers among the financial institutions in Southern Africa. They therefore were regarded as the "institutional investors."

The second questionnaire was distributed in August 1985 to a sample of 2500 persons on the mailing list of active investors of a firm of Johannesburg stockbrokers. The firm was reputed to have the largest private client base in the country. The sampling was done on a systematic basis, with every third name on the broker's alphabetic mailing list being selected.

Respondents were asked to assess the risk of each stock on a scale of one (low) to five (high). This scale was adopted because it was felt that investors can effectively discriminate risk assessments on a scale of five integers only. 
Respondents were to assume that the stock would be added to a diversified portfolio. We agree with Farrelly and Reichenstein $(1984$, p. 7) that "Interpretation of the risk ratings requires establishment of the setting in which the stock's risk should be assessed."

The 123 responses $(27.3 \%)$ were received from the institutional investors within a threeweek period. This is a week longer that the period used in the U. S. studies and reflects the less efficient postal services in South Africa. In this sample, 104 usable responses for the Gold shares and 111 responses for the Industrial/Financial shares were received. The institutional investor respondents reported their occupations as follows:

$\begin{array}{ll}\text { Investment Analysts } & 38 \% \\ \text { Portfolio Managers } & 36 \% \\ \text { Stockbrokers } & 16 \% \\ \text { Academics } & 1 \% \\ \text { Other } & 9 \%\end{array}$

499 responses $(20 \%)$ were received from the individual investors; 362 respondents rated the Gold shares and 415 respondents rated the Industrial/Financial shares. They reported their occupations as follows:

$\begin{array}{ll}\text { Professional/Technical } & 32 \% \\ \text { Managers } & 15 \% \\ \text { Self-employed } & 11 \% \\ \text { Retired } & 26 \% \\ \text { Other } & 16 \%\end{array}$

\section{Empirical Analysis}

Mean risk ratings for each share (and the standard deviation of the ratings) were calculated for each sample of investors. The mean risk ratings for each share were ranked and correlated, using Spearman's Coefficient of Correlation, against other measures of risk--one measure of systematic risk (beta) and two risk measures more inclusive than beta (total market risk and earnings variability). Because of the limited availability of data in South Africa, the list is more limited than that used in the American studies. Correlation analysis, comparing individual to institutional perceptions, was also carried out, although this was limited to a certain extent by the relatively small sample size of the institutional investor group.
The Beta Values used are those calculated by McKie, Van Velden Inc., member of the Johannesburg Stock Exchange. Separate betas are provided for the All Mining Market, the Industrial and Financial Market and the All Shares Market.

The implication of beta, as given by the CA$\mathrm{PM}$, is that movements in an underlying, independent factor (the market) will result in changes in the expected return for a given share. This is a questionable assumption in the South African context. South Africa is the world's major gold producer, with gold accounting for more than $30 \%$ of total export earnings.

The mining sector of the Johannesburg Stock Exchange, which comprises approximately $44 \%$ of the total market capitalization, is largely dependent on the gold price. The industrial sector, on the other hand, is more broadly affected by the general sweep of economic ("market") events. The question can then be posed as to whether the market portfolio in the South African context could better be described as having two underlying factors, rather than a single factor.

Some doubt, therefore, exists as to the suitability of the "All-Share Index" as the reference point for the calculation of beta coefficients. Gilbertson and Goldberg (1982) suggest that a two-factor Capital Assets Pricing Model best describes South African share returns, and that the "All Mining Index" and the "Industrial and Financial Index" should be used to measure betas of mining and financial/industrial shares respectively in situations where only a single class of shares are being considered.

Thus, the extent to which risk perceptions correlate to systematic risk can be tested both against "All Share Betas" as well as "Mining/ Non-mining Beta\#" rather than the "All-Share" beta traditionally used in U.S. studies.

The source of the Total Risk values is also McKie, Van Velden Inc. Values for each share are different when calculations based on the "all share" index and on the "mining/financial industrial" index are used, due to the particular methodology used by McKie, Van Velden in order to overcome bias introduced by non-trading weeks.

Because of the thinness of trading of many 
shares on the Johannesburg Stock Exchange, some shares which are considered to be well traded may display no trading in a few of the weeks being used in the beta calculation. In order to avoid nontrading bias, these weeks are dropped from the regression calculation. In order to estimate the total risk of shares which exhibit some non-trading weeks, the standard deviation of returns of the shares, as calculated from the returns observed during weeks when the share is traded, is adjusted by the ratio of the standard deviation of the returns of the particular market index under consideration divided by that standard deviation obtained by considering the returns in the index only in those periods when the share was observed to trade.

Earnings Variability is based on the standard deviation as a percentage of the mean annual net profit before tax over a five-year period. The values used in this study have been calculated in the following manner. The mean of the net operating income before tax (NOIBT) over a five-year period, 1980-1984 inclusive, was determined and the Standard Deviation was computed. The Standard Deviation as a percentage of the mean was then used to reflect the earnings variability. Using Vaal Reefs as an example:

\begin{tabular}{llrrrr}
\hline YEAR & (NOIBT) & $\mathrm{X}_{i}-\overline{\mathrm{X}}$ & $\left(\mathrm{X}_{i}-\overline{\mathrm{X}}\right)^{2}$ & STD DEVN & $\%$ \\
\hline 1980 & 712 & 59 & 3481 & & \\
1981 & 542 & -111 & 12321 & & \\
1982 & 539 & -114 & 12996 & & \\
1983 & 692 & 39 & 1521 & & \\
1984 & 781 & 128 & 16384 & & 16.5 \\
\hline
\end{tabular}

\section{Results and Discussion}

\section{Individual vs. Institutional Perceptions}

Table 1 shows the mean and standard deviation for each of the 26 stocks as rated by the investors and the analysts. There is a fair degree of agreement between the two groups, as evidenced by the following averages computed from the tabulated results.

\begin{tabular}{|c|c|c|c|c|}
\hline & & ESTMENT ANALYSTS & INDI & INVESTORS \\
\hline & MEAN & STANDARD DEVIATION & MEAN & DEVIATION \\
\hline Gold & 2.90 & .89 & 2.70 & .88 \\
\hline Ind/Fin & 2.87 & .77 & 2.54 & .79 \\
\hline
\end{tabular}

This similarity in perceptions is in contrast to the findings of Gooding (1975), who concluded that significant differences may exist between the average perceptions of portfolio managers and nonprofessional investors. Perhaps in South Africa the private investor's information set on the stocks is in the main derived from information supplied by professional investment advisors. Thus there is a high degree of commonality of information amongst the two investor groups. Nonetheless, the extent of the similarity in rankings goes far beyond what might appear to be a vaguely defined common set of information. 
Table 1

Risk Perceptions on a Scale of 1 (Low) to 5 (High)

\begin{tabular}{|c|c|c|c|c|c|c|}
\hline \multirow[b]{2}{*}{ GOID STOCKS } & \multicolumn{3}{|c|}{ INSTITUTIONAI INVESTORS } & \multicolumn{3}{|c|}{ INDIVIDUAL INVESTORS } \\
\hline & MEAN & $\begin{array}{l}\text { STANDARD } \\
\text { DEVIATION }\end{array}$ & RANK & MEAN & $\begin{array}{l}\text { STANDARD } \\
\text { DEVIATION }\end{array}$ & RANK \\
\hline Vaal Reefs & 1.59 & 0.80 & 1 & 1.77 & 0.73 & 1 \\
\hline Kloof & 1.76 & 0.74 & 2 & 1.98 & 0.80 & 3 \\
\hline Randfontein & 1.84 & 0.82 & 3 & 1.91 & 0.79 & 2 \\
\hline Western Deeps & 2.03 & 0.86 & 4 & 2.15 & 0.80 & 4 \\
\hline Kinross & 2.25 & 0.96 & 5 & 2.75 & 0.85 & 7 \\
\hline Elandsrand & 2.53 & 0.74 & 6 & 2.51 & 0.81 & 5 \\
\hline ERGO & 2.51 & 1.08 & 7 & 2.56 & 0.89 & 6 \\
\hline Harmony & 3.05 & 0.87 & 8 & 2.77 & 0.86 & 8 \\
\hline Loraine & 3.80 & 0.94 & 9 & 3.28 & 0.94 & 11 \\
\hline Stilfontein & 3.85 & 0.96 & 10 & 3.16 & 0.95 & 9 \\
\hline East Dagga & 3.92 & 0.98 & 11 & 3.44 & 1.01 & 12 \\
\hline West Rand Cons & 4.21 & 0.05 & 12 & 3.26 & 1.01 & 10 \\
\hline South Roodepoort & 4.33 & 0.86 & 13 & 3.58 & 1.03 & 13 \\
\hline
\end{tabular}

INDUSTRIAL/FINANCIAL STOCKS

\begin{tabular}{lllllll}
\hline Sasol & 1.31 & 0.50 & 1 & 1.58 & 0.67 & 1 \\
Liberty Life & 1.33 & 0.62 & 2 & 1.60 & 0.69 & 2 \\
Barlows & 1.96 & 0.84 & 3 & 1.80 & 0.78 & 4 \\
S A Breweries & 1.96 & 0.71 & 4 & 1.69 & 0.64 & 3 \\
AECI & 2.41 & 0.87 & 5 & 2.10 & 0.79 & 6 \\
AMIC & 2.46 & 0.87 & 6 & 2.09 & 0.80 & 5 \\
Edgars & 2.79 & 0.97 & 7 & 2.48 & 0.85 & 7 \\
O K Bazaars & 3.19 & 0.78 & 8 & 2.53 & 0.83 & 8 \\
Amalg Retail & 3.58 & 0.79 & 9 & 3.13 & 0.73 & 9 \\
Metro & 3.70 & 0.94 & 10 & 3.16 & 0.84 & 10 \\
Ellerine & 3.93 & 0.77 & 11 & 3.45 & 0.85 & 11 \\
Williams Hunt & 4.00 & 0.74 & 12 & 3.66 & 0.81 & 12 \\
Tedelex & 4.71 & 0.58 & 13 & 3.76 & 1.01 & 13
\end{tabular}


The results imply that either the two investor groups are in fact not very diverse, or perhaps that the relatively small size of the Johannesburg Stock Exchange (some 500 stocks at the time of the study) is such that the relative level of risk of stocks is easily established by all classes of investors. Certainly in the industrial sector, very well-known and widely traded stocks were chosen; but the gold stocks represented a randomly chosen sample.

The professionals, however, do appear to perceive more risk than the individual investors. The average risk ratings of the analysts are about ten percent higher than the ratings estimated by the investors, although the standard deviations are almost identical between these two groups. Both sets of respondents rate Gold shares riskier than Industrial/Financial shares as far as the mean risk assessments are concerned and the higher standard deviations of the Gold shares also reflect greater uncertainty.

Figures 1 and 2 illustrate the mean risk ratings plotted against the standard deviations. The "backwards C" curve of the Industrial/Financial shares (see Figure 1) indicated that there is a trend towards lower standard deviations when the risk rating is either very low or very high. Thus, there is a consensus of opinion for "bluechip" shares at one end of the spectrum and high risk shares at the other. There is more disagreement for the shares between the two spectrums.

\section{Systematic vs. Total Risk}

According to modern portfolio theory, the market only values systematic risk. The results contained herein cause one to question this hypothesis. As previously mentioned, correlations between risk perceptions and three measures of risk were computed:

-beta (actually three separate betas: all market, all mining, all industrial/financial)

-total risk

-earnings variability

The Ranking Correlation Summary, Table 2, indicates that investor perceptions of risk correlate best with earnings variability, next best with total risk measures, and worst with beta.

Each of the three measures of risk performed as follows:

\section{Beta Values}

As Table 2 indicates, on a comparative basis, the correlations between risk perceptions and beta are quite low. The other explanatory variables (earnings variability and total risk) performed much better than beta in "explaining" perceived risk.

The beta analysis also indicates that there is justification for the use of separate markets on the Johannesburg Stock Exchange. With the exception of the Investment Analysts' Gold ratings, all the correlations are higher for the particular market (All Mining or Industrial/Financial) than for the All Shares Market. This supports the evidence of Gilbertson and Goldberg (1982) and Handley (1985) that the two major sectors of the Johannesburg Stock Exchange (Mining and Industrial) are so different that better betas arise from regression against the separate sectoral indexes.

It is evident from Table 2 that two "different" betas were used in the study. We thought it possible that the relatively poor correlation between risk perceptions and the 1985 beta may be due to the fact that the betas were "ex post" but the analysts/investors perceptions were "ex ante." This, of course, is a difficulty encountered with the use of any risk measure. It is based on past data, but it attempts to explain expected return. Thus, the correlations were repeated one year later on a set of betas based on a further year's return data; these betas were termed "1986" betas. Through these, it was hoped that a better "match" of perceived risk and measured systematic risk would be found. In all cases, except for individual investors' rankings correlated against gold betas (All Share), the correlation coefficients showed slight increases compared to the correlations obtained using the 1985 betas. In general, however, the explanatory power of beta -- whether 1985 or 1986 was quite low.

\section{Total Risk Values}

Total Risk equals or betters the correlation achieved with betas. The improvement is particularly noticeable for the Industrial-Financial shares, where the Industrial/Financial Total Risk correlation is more than thirty percent higher, 

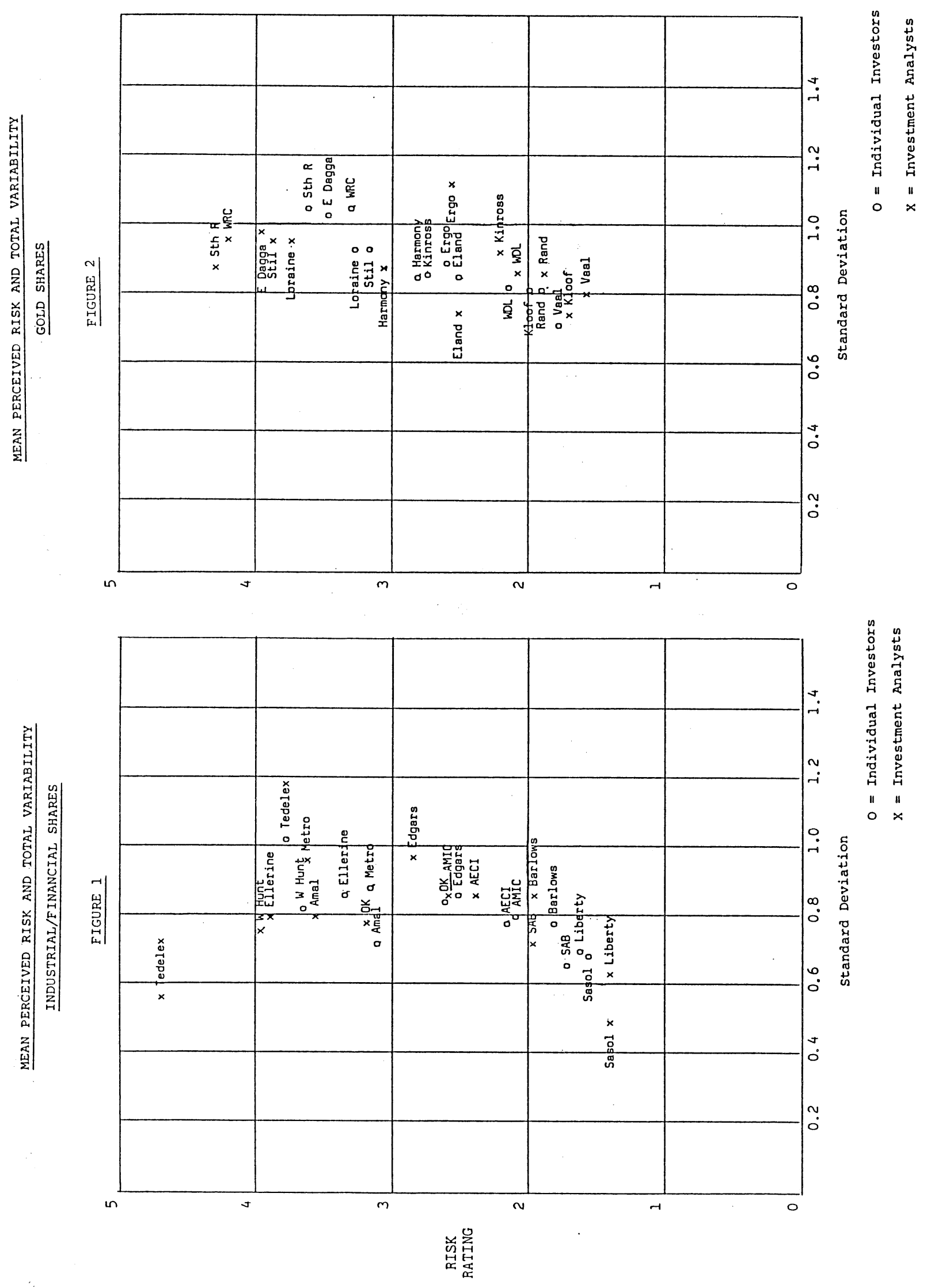
$\underline{\text { Table } 2}$

Perceived Risk Correlated with Selected Risk Measures

\begin{tabular}{|c|c|c|c|c|c|c|c|c|}
\hline RISK MEASURES & $\begin{array}{c}\text { INVESTORS } \\
\text { GOLD } \\
\end{array}$ & RANK & $\begin{array}{c}\text { INVESTORS } \\
\text { IND/FIN }\end{array}$ & RANK & $\begin{array}{l}\text { ANALYSTS } \\
\text { GOLD }\end{array}$ & RANK & $\begin{array}{l}\text { ANALYSTS } \\
\text { IND/FIN }\end{array}$ & RANK \\
\hline $\begin{array}{l}\text { All Mining } \\
\text { Beta } 1985 \\
\text { Beta } 1986\end{array}$ & $\begin{array}{l}.64 \\
.67\end{array}$ & $\begin{array}{l}5 \\
3\end{array}$ & & & $\begin{array}{l}.60 \\
.63\end{array}$ & $\begin{array}{l}7 \\
6\end{array}$ & & \\
\hline $\begin{array}{l}\text { Ind/Fin } \\
\text { Beta } 1985 \\
\text { Beta } 1986\end{array}$ & & & $\begin{array}{l}.51 \\
.53\end{array}$ & $\begin{array}{l}5 \\
4\end{array}$ & & & $\begin{array}{l}.51 \\
.51\end{array}$ & $\begin{array}{l}4 \\
4\end{array}$ \\
\hline $\begin{array}{l}\text { All Shares } \\
\text { Beta } 1985 \\
\text { Beta } 1986\end{array}$ & $\begin{array}{l}.61 \\
.67\end{array}$ & $\begin{array}{l}6 \\
3\end{array}$ & $\begin{array}{l}.47 \\
.40\end{array}$ & $\begin{array}{l}6 \\
7\end{array}$ & $\begin{array}{l}.67 \\
.71\end{array}$ & $\begin{array}{l}5 \\
3\end{array}$ & $\begin{array}{l}.34 \\
.36\end{array}$ & $\begin{array}{l}7 \\
6\end{array}$ \\
\hline $\begin{array}{l}\text { All Mining } \\
\text { Total Risk }\end{array}$ & .70 & 2 & & & .72 & 2 & & \\
\hline $\begin{array}{l}\text { Ind/Fin } \\
\text { Total Risk }\end{array}$ & & & .71 & 3 & & & .66 & 2 \\
\hline $\begin{array}{l}\text { All Shares } \\
\text { Total Risk }\end{array}$ & .61 & 6 & .74 & 2 & .70 & 4 & .56 & 3 \\
\hline $\begin{array}{l}\text { Earnings } \\
\text { Variability }\end{array}$ & .87 & 1 & .86 & 1 & .80 & 1 & .69 & 1 \\
\hline
\end{tabular}

Analysts' risk perception versus Investors' risk perception for:

$\begin{array}{ll}\text { Gold: } & .951 \\ \text { Ind/Fin: } & .989\end{array}$

and the All Shares Total Risk correlation is more than fifty percent higher, than with beta.

\section{Earnings Variability}

The highest correlation is achieved against Earnings Variability. Thus, despite the implications of modern portfolio theory, analysts' and investors' risk perceptions are more highly correlated with measures of total risk rather than any of the betas used. The high correlation between earnings variability and risk perception is interesting, especially since earnings variability is a measure that includes no market data at all, but merely company performance (that is net income) data.

\section{Conclusion}

The results, based on the Johannesburg Stock
Exchange, agree with Farrelly and Reichenstein (1984) that analyst risk perceptions are more highly correlated with measures of risk that are more inclusive than systematic risk measures. This agreement serves as a reminder that the capital asset pricing model, although its power is impressive, does not capture all the inputs that investors use to make their investment decisions.

Also, analysis of the various systematic measures used (i.e., industrial/financial betas, gold betas, and all-market betas) indicates that "industry" betas perform better than the all-market beta. Both total risk and earnings variability perform better than beta, but the specific betas perform better than the general one. The one beta measure does not serve equally well for both kinds of stocks.

In this particular study, there was much agree- 
ment between individual and institutional investor perceptions. This analysis was limited to a certain extent by the relatively small sample size of the institutional investor group, particularly in relation to the size of the individual investor group. And this, of course, is not the only limitation of this survey. Risk perception research, unlike the more traditional research in finance (research which models the market) can deal with only a small portion of the entire market; and then, even within the population sampled, there is always the possibility of non-response bias.

On the other hand, perhaps we should apply to the discipline of finance Whitehead's (1967, p. vii) comment that philosophy "...has to insist on the scrutiny of the ultimate ideas, and on the retention of the whole of the evidence in shaping our cosmological scheme." Financial research employing mathematical modeling of the market as a whole will, no doubt, continue to achieve impressive results. But if we limit ourselves to this technique, and do not supplement it by investigating the behavior of individuals, we may be missing the "whole of the evidence." Blume and Friend $(1973$, p. 32), point out that "...the beta coefficient only measures part of what investors mean by risk...." Analyzing risk perceptions may help us to better understand what investors mean by risk; ultimately, such analysis may help us to better understand why people and prices in financial markets often behave in ways that current financial theory simply cannot explain.

Farrelly and Reichenstein (1984, p. 10) suggest that, to a large extent, market-wide measures of risk "leave much to be desired in terms of their ability to explain risk perception and, presumably, the pricing of risk in financial markets ....We simply do not know enough about what makes investors perceive and react to risk." The present study indicates that this finding applies to the stock exchange in Johannesburg as well as those in the United States.

\section{References}

1. $\quad$ Arrow, K. J., "Risk Perception in Psychology and Economics," Economic Inquiry, January, 1982.

2. Blume, M. E. and I. Friend, "A new Look at the Capital Asset Pricing Model," Journal of Finance, March, 1973.

3. $\quad$ Bowman, E. H., "Risk Seeking by Troubled Firms," Sloan Management Review, Summer, 1982.

4. Carter, K. J., J. F. Affleck-Graves, and A. H. Money, "Are Gold Shares Better than Gold for Diversification?" The Journal of Portfolio Management, Fall, 1982.

5. Cooley, P. L., "A Multidimensional Analysis of Institutional Investor Perception of Risk," Journal of Finance, March, 1977.

6. Crum, R. L., D. J. Laughhunn, and J. W. Payne, "Risk Seeking Behavior and Its Implications for Financial Models," Financial Management, Winter, 1981.

7. Farrelly, G. E. and W. R. Reichenstein, "Risk Perceptions of Institutional Investors," Journal of Portfolio Management, Summer, 1984.

8. Gilbertson, B. and M. Goldberg, "The Market Model and the Johannesburg Stock Exchange," The Investment Analysts Journal (South Africa), August, 1982.

9. Gooding, A. E., "Quantification of Investors' Perceptions of Common Stock: Risk and Return Dimensions," Journal of Finance, December, 1975.

10. Handley, P. A. C., "Two-Dimensional Betas on the Johannesburg Stock Exchange," unpublished MBA Dissertation, Graduate School of Business Administration, University of Witwatersrand, Johannesburg, 1985.

11. McDonald, J. G. and R. E. Stehle, "How Do Institutional Investors Perceive Risk?" Journal of Portfolio Management, Fall, 1975.

12. Whitehead, A. N. Science and the Modern World, Free Press, New York, 1967. 


\section{APPENDIX}

\section{Sample Questionnaire}

What is your estimate of the riskiness, over the next year of each of the shares on the following list? Assume that you are adding the share to an existing diversified portfolio of shares. Please assign a risk rating from 1 (low risk) to 5 (high risk) for each of the shares.

The shares are divided into two groups: gold mining shares and industrial shares. Although you may not be as familiar with some shares as with others, you are requested not to omit any ratings, but rather to make an 'educated guess.'

\begin{tabular}{|c|c|c|c|c|}
\hline GOLD & SHARES & $\begin{array}{l}\text { RISK RATING } \\
(1=\text { low risk } \\
5=\text { high risk) }\end{array}$ & INDUSTRIAL SHARES & $\begin{array}{l}\text { RISK RATING } \\
(1=1 \text { ow risk } \\
5=\text { high risk) }\end{array}$ \\
\hline 1. & Loraine & & 14. Sasol & \\
\hline 2. & Western Deep Levels & & 15. Barlows & \\
\hline 3. & E.R.G.O. & & 16. A.E.C.I. & \\
\hline 4. & Kloof & & 17. AMIC & \\
\hline 5. & South Roodepoort & & 18. Tedelex & \\
\hline 6. & East Dagga & & 19. Liberty Life & \\
\hline 7. & stilfontein & & 20. Edgars & \\
\hline 8. & Vaal Reef & & 21. Williams Hunt & \\
\hline 9. & Elandsrand & & 22. Amalg Retail & \\
\hline 10. & Randfontein & & 23. Ellerine & \\
\hline 11. & Kinross & & 24. Metro & \\
\hline 12. & Harmony & & 25. S A Breweries & \\
\hline 13. & West Rand Cons & & 26. Bazaars & \\
\hline
\end{tabular}

